\title{
電子ビームを用いた金属 Additive Manufacturing 技術の最新動向* \\ Recent Trends of Additive Manufacturing Using Electron Beam Melting
}

\section{千葉晶彦** \\ Akihiko CHIBA}

\section{1.は じめに}

電子ビーム積層造形技術は, 以下の二つのタイプが知ら れている。一つは, 三次元 $\mathrm{CAD}$ データに基づく電子ビー ム走査により，50〜100 $\mu \mathrm{m}$ 程度の厚さに敷き詰めた金属 粉末床（パウダーベッド）を選択的に溶融・凝固させた層 を繰り返し積層させて三次元構造体を製作する(パウダー ベッド溶融結合法 $)^{1)}$. また, もう一つは, 繰り出した合 金ワイヤーを電子ビームにより溶融させ液滴を基板上に堆 積（デポジション）させて, 三次元構造体を製作するタイ プ（指向エネルギー体積法）である. 前者のタイプは, 高 精度な積層造形加工技術として航空機部品や人工関節など の医療用製品の製造技術として広く普及している.

本稿では，電子ビームパウダーベッド溶融（電子ビーム 積層造形）法に焦点を絞り，いくつかの話題を取り上げ, 電子ビーム積層造形技術の現状と最新動向について述べ る.

\section{2. 電子ビーム積層造形装置構成}

市販されている電子ビーム積層造形 (EBM) 装置は, ArcamAB 社（1997 年創立）が製造する装置が現在まで 唯一である。その開発の歴史は, レーザー積層造形に比較 して浅い. 電子ビーム方式による Additive Manufacturing （AM）技術は, 真空中での造形を基本とするため, 装置 構成が複雑となる。 パウダーベッド方式に限っていえば, 電子ビームでの選択的溶融プロセスに入る前に，パウダー ベッド表面を $700 \sim 1000^{\circ} \mathrm{C}$ の高温に予備加熱する必要があ る.この予備加熱プロセスは, レーザー方式にはなく, EBMに独特なプロセスである. その材料学的な意味につ いては後述する。ここでは, Arcam 社の EBM 装置を例 にとり，EBM 造形技術と装置概要について説明する。

\section{1 装置構成と造形法}

図 1 に（a）EBM 装置外観拀よび（b）造形装置概略図

*原稿受付 平成 28 年 6 月 1 日

*東北大学金属材料研究所（宮城県仙台市青葉区片平 2-1-1）
を示す。また，図 2 には，造形プロセス開始時からの一 層分のプロセス (1)スタートプレート予熱 $\rightarrow$ (2)パウダーベ ッド形成 $\rightarrow$ (3)パウダーベッド予備加熱 $\rightarrow$ (4)選択的溶融 $\rightarrow$ (5) ステップダウン）を模式的に示す，次に述べる手順により 造形を行う。以下の括弧内の数值は, 図 1 (b) に現れる 数字と対応している.

A）加熱されたタングステンフィラメント（1）から放 出された電子はアノード（2）を通って加速される.

B）加速された電子はフォーカルコイル（3）により焦 点が合わされ，ディフレクションコイル（4）により 走査 (偏向) される.

C）電子がパウダーベッドに照射されたときの運動エ ネルギーが熱に変換され，この熱によって金属粉末が 加熱あるいは溶融する。 まず, 造形開始時に, 電子ビ ーム照射によりスタートプレートのみを $600 \sim 1000^{\circ} \mathrm{C}$ の温度に加熱する (図 2 (1)）。この予備加熱されたス タートプレート上にレーキアームによって厚さ $50 \sim 80 \mu \mathrm{m}$ のパウダーベッドを形成する（図 2 (2)

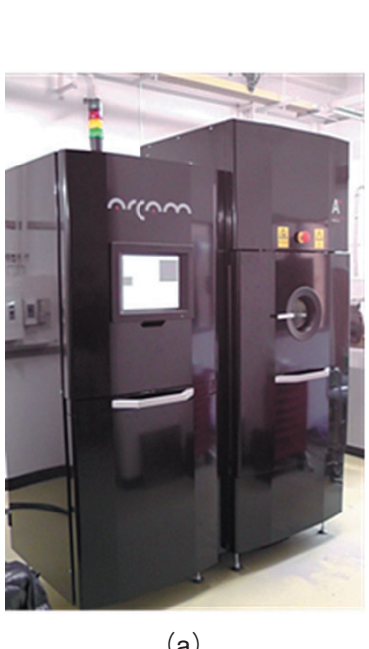

(a)

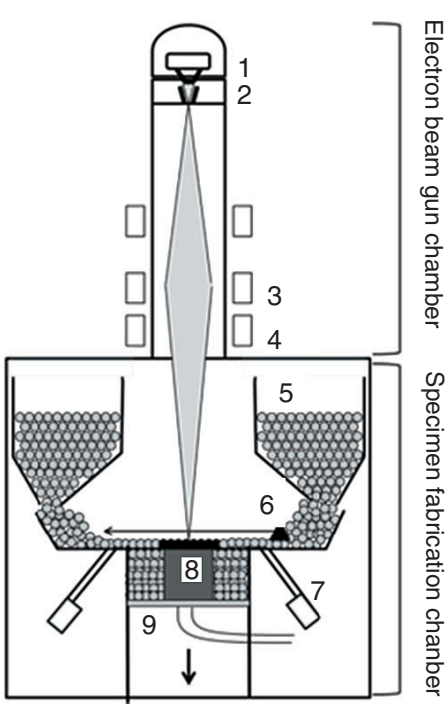

(b)
図 1 （a）EBM 装置の外観および（b）装置チャンバの模式図 


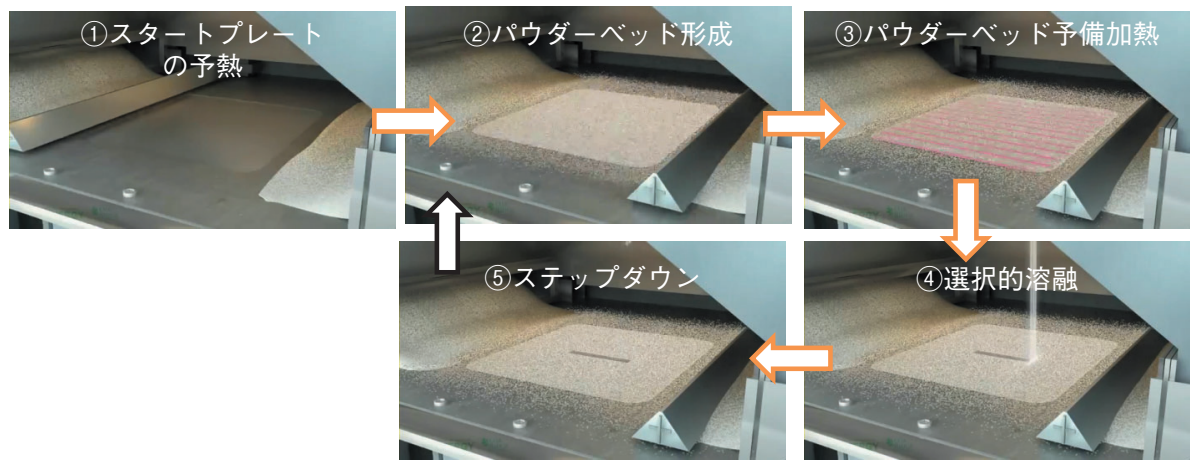

図 2 電子ビーム積層造形の 1 層分の造形プロセス

表 1 EBM とレーザー積層造形比較

\begin{tabular}{|c|c|c|}
\hline & 電子ビーム積層造形 & レーザー積層造形 \\
\hline 装置名 & ARCAM 社：EBM A2 & EOS 社：EOSINT M 280 \\
\hline 熱源 & $\begin{array}{c}\text { 電子ビーム } \\
(\mathrm{W} \text { フィラメント) }\end{array}$ & Yb-fibre レーザー \\
\hline $\begin{array}{c}\text { 造形可能サイズ } \\
(\mathrm{W} \times \mathrm{D} \times \mathrm{H})\end{array}$ & $200 \times 200 \times 350$ & $250 \times 250 \times 325$ \\
\hline 最大出力 & $3500 \mathrm{~W}$ & $400 \mathrm{~W}$ \\
\hline ビーム径 & $0.2 \sim 1.0 \mathrm{~mm}$ & $0.1 \sim 0.5 \mathrm{~mm}$ \\
\hline $\begin{array}{c}\text { 最大スキャン } \\
\text { 速度 }\end{array}$ & $8000 \mathrm{~m} / \mathrm{s}$ & $7 \mathrm{~m} / \mathrm{s}$ \\
\hline 造形速度 & $15 \sim 22 \mathrm{~mm}^{3} / \mathrm{s}$ & $2 \sim 8 \mathrm{~mm}^{3} / \mathrm{s}$ \\
\hline 造形雲囲気 & $\begin{array}{c}\text { 高真空 }\left(10^{-5} \mathrm{mbar}\right) \text { 後 } \\
\text { He ガス導入 }\left(10^{-3} \mathrm{mbar}\right)\end{array}$ & $\left(\mathrm{Ar}\right.$ or $\left.\mathrm{N}_{2}\right)$ ガス置換 \\
\hline 予備加熱温度 & $\begin{array}{c}(0.5 \sim 0.8) \quad \mathrm{T}_{\mathrm{m}} \\
\left(\mathrm{T}_{\mathrm{m}} \text { : 融点 }(\mathrm{K})\right)\end{array}$ & $\sim 90^{\circ} \mathrm{C}$ \\
\hline
\end{tabular}

と, 余熱によってパウダーベッドは加熱され，スター トプレートと同程度にまで昇温させることができる。 600 $1000^{\circ} \mathrm{C}$ の温度に加熱されたパウダーベッドに電 子ビームを照射し, あらかじめ定めていた温度に到達 するまで加熱する（図 2 (3)），その後に，目的とする 造形物の 3DCAD データの 2D のスライスデータ領域 を選択的に溶融する（図 2 (4)）。

D） 2D スライスデータによる溶融プロセスが終了した 後，ステージ（9）が1層分降下し（図 2 (5)), パウダ ーホッパー（5）からレーキアーム（6）を用いて新た にパウダーベッドを形成する。その際に供給される粉 末の量は，センサー（7）を用いて一定量になるよう にレーキアームの位置を随時調整する.

E）以上の過程を繰り返し行い，2D スライスデータの 溶融層を繰り返し積層し, 製品（8）形状に成形する。

\subsection{EBM 造形法の特徵}

a. 熱源および出力

表 1 に，EBM 装置（ArcamAB 社，A2X）とレーザー 積層造形（LBM）装置（EOS 社，EOSINT M 280）の仕 様を示す。熱源として，EBM 装置ではタングステンフィ ラメントを用いており（ただし，最新鋭の EBM 装置 （Q20）では $\mathrm{LaB}_{6}$ を搭載している)，LBM（装置）では
$\mathrm{Yb}$ のファイバーレーザーを使用している，EBM 装置で

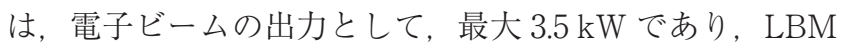
の最大出力 $0.4 \mathrm{~kW}$ に比べて大きい. このため, EBM で は LBM に比べ高融点合金にも適用可能である.

b. スキャン速度

レーザービームのスキャン速度は $7 \mathrm{~m} / \mathrm{s}$ であるのに対 して, 電子ビームのスキャン速度は $8000 \mathrm{~m} / \mathrm{s}$ と極めて高 速である。これは，電子ビームのスキャン方法が電子レン ズによる電磁気的なビーム偏向であるのに対し，レーザー のそれはガルバノミラーの，機械的制御により偏向させる ことに起因する。 ガルバノメーターミラーの, 自重による 慣性力の高精度な制御に限界があり，高速度で偏向させる ことが難しいためである。

c. 造形雲囲気

EBM プロセスでは, 高真空下で溶融造形を行うため酸 化の影響がない。 むしろ, ニッケル基超合金やチタン合金 などでは, 造形物の酸素濃度が使用した粉末の酸素濃度よ りも低下させる効果が認められており, 高純度造形が可能 である。実際には造形中に $\mathrm{He}$ ガスをわずかに導入する が，これは電子ビーム照射による金属粉末の带電（チャー ジアップ）を防ぐためである，LBM ではアルゴン等の不 活性ガスを充満させて造形を行うため, EBM における真 空チャンバーに必要な耐圧設計が不要であり, 低剛性のチ ヤンバー設計で足りるという利点がある. しかし, 最近, LBM においても造形中の酸化を防止するため, 真空中で 造形するタイプの装置が開発されている2). また, LBM の最新機種の中には, いったん真空排気を行ってからアル ゴンガスを導入置換して造形する装置が開発されるなど, 造形中の酸化防止に配慮した LBM 装置が開発されるよう になった。

\section{d. 予備加熱}

$\mathrm{EBM}$ 造形では, パウダーベッドの溶融プロセスの前に パウダーベッドの予備加熱を行う, ホットプロセス（Hot process）が基本であることは既に述べた。これは，電子 ビームを予備加熱していないパウダーベッドに照射する と, 粉末が霧状に舞い上がる（スモークと呼んでいる）現 象が起こり，造形ができなくなる。このため, $\mathrm{EBM}$ 造形 


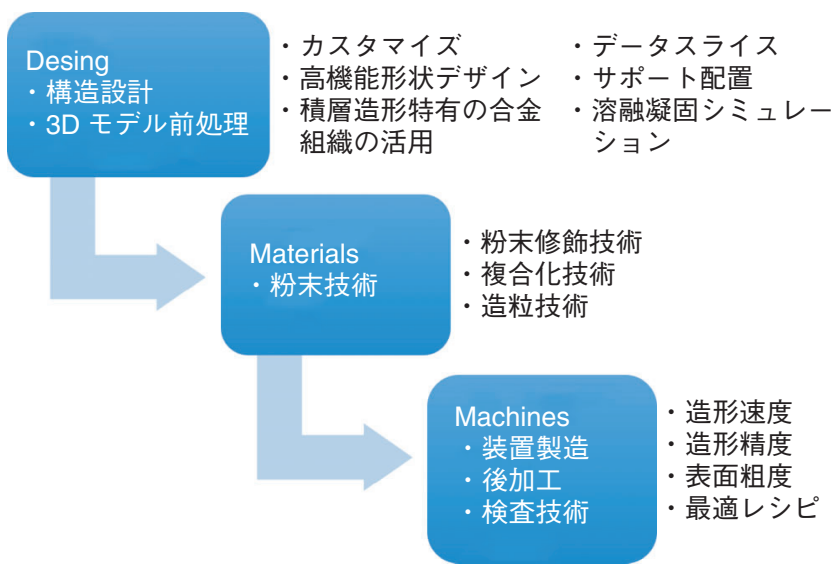

図 3 金属積層造形技術の 3 要素と開発課題

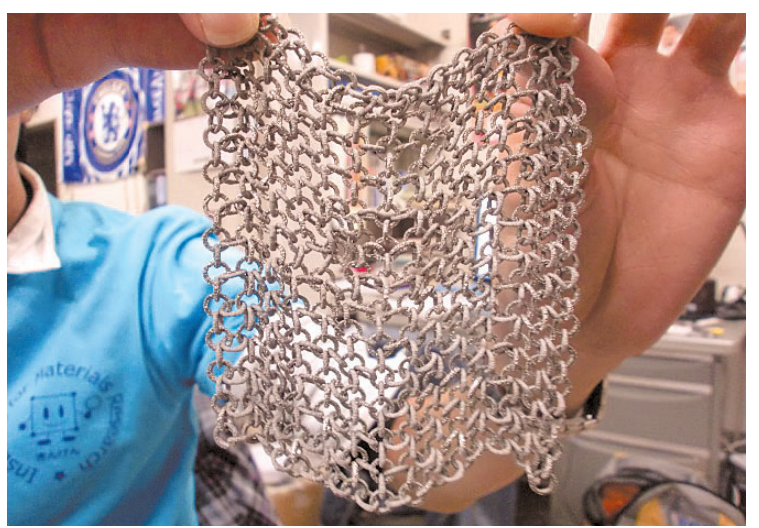

図4 電子ビーム積層造形によって造形された CCM 合金製鎖帷子 サポートフリーで造形可能である。

術として，「トポロジー構造最適化」が注目されている. このトポロジー構造最適化技術を取り入れたものづくり は，金属積層造形技術と組み合わせることで強みを発揮す る。このように，金属積層造形技術は，設計技術の革新を も斢引するものづくり技術として発展するものと考えられ る.

デザイン技術としてほかに，造形用 $3 \mathrm{D}$ デー夕を扱うソ フトウエアもまた重要となる。 3D データの変換, 修正か ら, サポートの設計, 造形プレート（プラットフォーム） 上への配置やスライスデー夕の作成に至るまで，3D 積層 造形プロセスの全体をカバーするソフトウエア技術も重要 な技術である。

これらの工程を 3D モデルの前処理工程と呼ぶことにす る。いかにこの前処理工程を機能的に実施するかが重要と なる，例えば，電子ビーム積層造形では溶融プロセスに移 行する前にパウダーベッドを $600 \sim 1000^{\circ} \mathrm{C}$ の温度に予備加 熱を行うことは前述した。 この予備加熱により，パウダー ベッドは仮焼結状態となり，造形中の造形物の自重を支え る「サポート」としての役割を果たすことができる。この 効果を $3 \mathrm{D}$ データの予備処理プロセスに考慮することによ り，より少ないサポート数の設定で造形が可能となる。図 4 に示したのは, サポートなしで造形された Co-28Cr$6 \mathrm{Mo}$ 合金製鎖帷子である. 溶融部以外のパウダーベッド は仮焼結されているため, オーバーハングがある造形でも サポートフリーでの造形が可能となる造形例として象徵的 である。このように, 電子ビーム造形技術の特徴を詳細に 分析することにより, 3D データの予備処理プロセスに反 映させることで，より複雑な形状の造形が容易となる。

今後の課題として, このような $3 \mathrm{D}$ データの予備処理技 術を高度化するためにも, 造形プロセス中でのパウダーベ ッドの温度分布や, 溶融池 (メルトプール) の高精度なモ ニタリング技術の開発などが挙げられる。

(2) マシン (造形装置) 技術

金属積層造形技術の実用化を促進するためには，造形速 度の高速化のほかにも，機械加工技術に匹敵する造形精度 


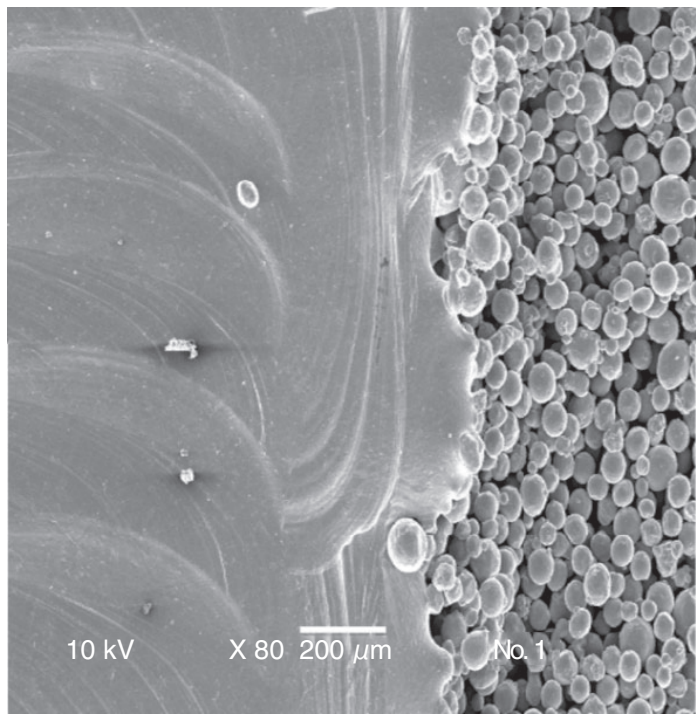

図 5 電子ビーム積層造形での溶融部と未溶融部との境界領域の SEM 像

および表面粗度の改善が求められる，以下に，造形装置技 術に関するいくつかの問題について現状と開発課題につい て述べる。

(1) 電子ビーム制御技術の高精度化

パウダーベッドに電子ビームを照射してメルトプール を形成する際の電子ビームによるエネルギー密度 $P$ は 以下の式により表現することができる゙3.

$$
P\left(\mathrm{~J} / \mathrm{mm}^{3}\right)=\frac{I \cdot V}{v \cdot d \cdot t}
$$

ここで, $I$ は電流値， $V$ は電子線の加速電圧， $v$ は電子 ビームの走査速度, $d$ は電子ビームの走査間隔, $t$ はパウ ダーベッドの積層厚さである.

まず, 式(1)には表れていない電子ビーム径の大きさの, 造形物品質に及ぼす影響について考える. 図 5 に示す溶 融部と未溶融部との境界領域（溶融領域端面）の SEM 像 から分かるように，溶融部端面の形状はビーム径 (200 $\mu \mathrm{m}$ 以上）を反映して波状にうねっている。このことよ り, 造形物の寸法精度や表面粗さの改善にとって, 電子ビ 一ム径の制御技術が重要であると理解することができる. ビーム径と表面粗さ, 粉末粒径との関倸について詳細な検 討が必要であるが，電子ビーム径を小さくして，高精度に 位置制御することができれば，溶融部端面をより微細化で き，表面粗さを改善することができる。したがって，電子 ビーム径を現状の $200 \mu \mathrm{m}$ 程度から数 $\mu \mathrm{m}$ 程度までに絞り 込む電子ビーム制御技術があれば，造形物の表面粗さを数 $\mu \mathrm{m}$ のオーダーまで改善することが可能になると考えられ る.

以上のように，電子ビームの高精度な位置制御とビーム 径の微細化技術により, 造形物の寸法精度と表面粗さを機 械加工仕上がりのレベルまで改善することが可能となる. 今後の電子ビーム制御技術のさらなる発展が期待される.

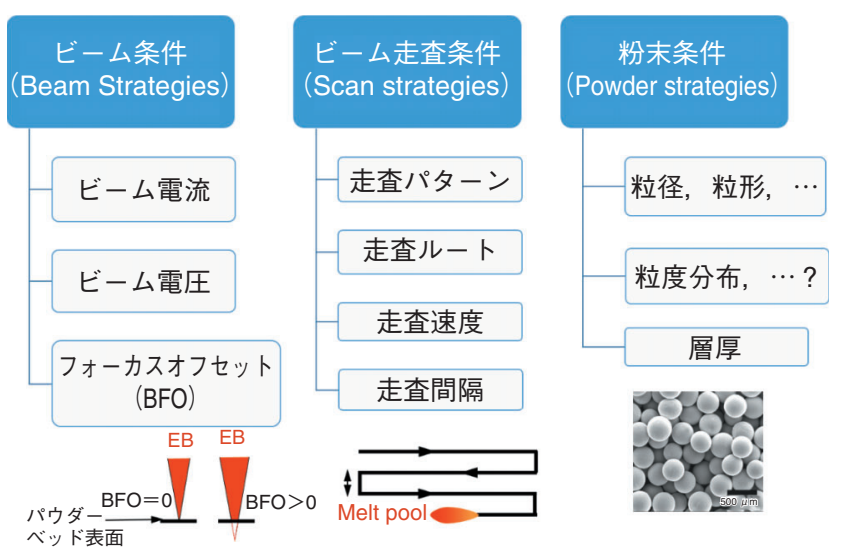

図 6 電子ビーム積層造形パラメータの最適化

(2) プロセスパラメータの最適化

欠陥のない健全な造形物の作製には，形成されたパウ ダーベッドに最適なエネルギー密度の值を選択すること が重要であるが, 式(1)はエネルギー密度が同じであっ ても, 走査速度, 走査間隔, 積層厚さなどのプロセスパ ラメータをさまざまに選択し得ることを意味している。 すなわち，エネルギー密度を一定に制御するだけではプ ロセスパラメータの選択の仕方によって形成されるメル トプールの形状や温度分布などに違いが生じて凝固形態 や凝固組織に違いが表れると予想される。

実際に，エネルギー密度一定でも，上述のプロセスパ ラメータを変えることにより形成される造形物の品質は 大きく変わることが知られている，すなわち，プロセス パラメータの選択を最適に行わなければ，装置側の制御 技術がいかに優れていても， 欠陥のない健全な造形物を 製作することができない.

図 6 に電子ビーム積層造形技術に関係するプロセスパ ラメータをまとめる。ビーム条件 (Beam strategies) と して, ビーム電流, ビーム電圧, フォーカスオフセット (ビーム径) などがある. ビーム走査条件 (Scan strategies）として, ビーム走查パターン, ビーム走査ルート, ビーム走查速度，ビーム走査間隔などがあり，これらの多 数のパラメータを最適に制御することによりメルトプール の形状，温度分布を最適化し，メルトプールの balling 現 象や溶け残りの発生に起因する欠陥が形成されない凝固プ ロセスとなる電子ビーム照射条件を最適化する必要があ る.

さらに，以上のビームに関係する最適パラメータ一つひ とつに, 粉末条件 (Powder strategies) を最適に設定す ることが求められる。このように, 電子ビーム積層造形技 術に扮いて，装置側の電子ビームに関倸する制御技術がい かに高度化したとしても, 造形パラメー夕の最適化が行わ れなければ，健全な造形物を製作することができない，す なわち, 装置技術のほかにも, 造形パラメー夕を最適化す る技術があって初めて電子ビーム積層造形技術による高度 なものづくりが可能となる. 
電子ビーム（レーザー）積層造形技術の難しさは，以上 述べた多数の造形プロセスパラメータの最適化が必要であ ること, その最適化には経験と勘だけに頼ったノウハウ構 築だけでは完成させることが困難である点を挙げることが できる。その意味からも，材料科学的な知見を基礎とし て，電子ビームと金属合金粉末との間で生じる相互作用を 詳細に記述する学理の確立とともに，高精度なメルトプー ルの溶融・凝固プロセスのシミュレーション技術の開発が 重要となる。

\section{4. お りに}

金属積層造形技術は, 金属合金粉末を用いて, 数十一数 百 $\mu \mathrm{m}$ の局所領域の溶融ゾーン（メルトプール）を形成さ せ，その凝固過程の最適化に関する金属加工学的な学術分 野であるといえる，既存の鋳造工学技術（Casting）に基 礎を置いてはいるが，局所領域に関する溶融凝固現象を 2 次元と 3 次元にわたって incremental に高精度に制御する 鋳造技術 (Incremental casting) と捉えることができる. これに関連して，最近，電子ビーム積層造形技術を用い て，単結晶のガスタービンブレード製造や，金属ガラス部 品の製造に関する研究開発が行われるようになってきてい る。今後, 組織制御や新たな材料開発ツールとしての電子 ビーム積層技術の可能性についても注目される.
謝辞

電子ビーム積層造形技術について共同研究で取り組んで いる, 小泉雄一郎, 山中謙太, 青柳健太, 佐々木信之の各 氏に謝意を表する。

\section{参 考 文 献}

1) L.E. Murr, S.M, Ramirez, D.A. Martinez, E. Herandez, J. Amato, K.N. Shindo, P.W. Medina, F.R. Wicker and R.B. Gytan: Metal Fabrication by Additive Manufacturing Using Laser and Electron Beam Melting Technologies, J. Mater Sci Techol., 28 (2012) 1-14.

2) 中野弾, 清水透, 佐藤直子：レーザー積層法を用いた金属部品 の積層技術，型技術，29（2014）28-31.

3) S. Bontha, N.W. Klinbeil, P.A. Kobryn and H.I. Fraser : J. Mater. Thermal process maps for predicting solidification microstructure in laser fabrication of thin-wall structures, Process. Technol., 178 (2006) 135-142.

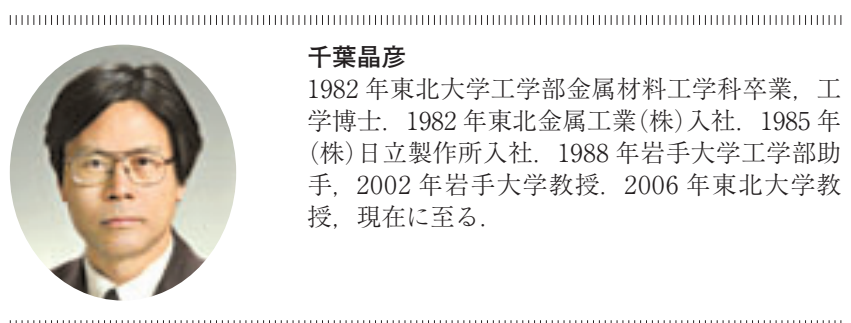

